\title{
Surface Water Quality Assessment of Warri Metropolis Using Water Quality Index
}

\author{
Asibor Godwin* and Ofuya Oborakpororo \\ Department of Environmental Management and Toxicology, Federal University of Petroleum \\ Resources Effurun, Delta State, Nigeria
}

asibor.godwin@fupre.edu.ng

Keywords: Surface water, Warri metropolis, WQI, weighted arithmetic index method

\begin{abstract}
The quality of the surface water (rivers) around Warri metropolis was evaluated using Water Quality Index (WQI) techniques. The study was carried out to assess the suitability of the water samples collected from different river bodies' around Warri metropolis. The water quality index (WQI) was determined based on their various physico-chemical parameters such as $\mathrm{pH}$, temperature, dissolved oxygen, electrical conductivity, total dissolves solids, total suspended solids, sulphates, nitrates, phosphates, chlorides, turbidity, biochemical oxygen demanded. The water quality indexes values obtained varied greatly from 110.12 to 821.5 . The result is quite high due to high turbidity $(9 \mathrm{mg} / 1-119 \mathrm{mg} / \mathrm{l})$ and total suspended solid $(10 \mathrm{mg} / \mathrm{l}-124 \mathrm{mg} / \mathrm{l})$. The presence of faecal coliform in the various water bodies is very alarming which ranges from $2-16 \mathrm{cfu}$ against the stated standard of nil by most regulatory agencies and as such may pose detrimental health effect when consumed by individuals within those areas if not properly treated. This may be due to poor waste management practice along the river's course. To avert this process, effective waste management and control along the water course should be encouraged.
\end{abstract}

\section{Introduction}

Water is one of the most important and basic natural resources and plays a crucial role in economic and social development processes [1-3]. Water is needed for several activities such as irrigation, industries, transport, drinking, bathing and several other purposes in everyday life. It is also essential for the disposal of wastes both urban sewage and dirt. About ninety-seven percent of water exists in oceans [4]. This huge amount of water is not suitable for drinking. In Agriculture, on the other hand, it is a major source of food for us. Thus, it is essential for raising food crops. Water is a tremendous and cheap resource for generating hydroelectricity; it is a renewable and pollution-free source of energy.

The total amount of water available on the earth is constant and adequate to meet all mankind demands, but its quality and distribution around the world is uneven. This uneven quality and distribution causes problems of scarcity and suitability, making mankind to develops and manages the scarce resources in a rational and efficient way. To accomplish these, there is a need to have accurate and adequate information about the quality of this commodity. Surface and groundwater are the two major sources of water whose qualities are assessed by chemists.

Surface waters are prone to contamination and therefore are generally poor in quality [5]. The large scale industrial growth has caused serious concerns regarding the susceptibility of surface water contamination due to discharge of waste materials. Contaminants are released into surface water easily be seepage from municipal landfills, septic tank effluents etc. The indiscriminate release of wastewater into surface waters is of serious concerns in cities lacking efficient waste disposal system or treatment plants. Therefore, the available quality of surface water is of utmost importance to ensure that it is potable for drinking at all time [6].

Water quality is a term used to express the suitability of water to sustain various uses or processes [7, 8] and comprises the chemical, physical and biological characteristics of water. Compliance is measured against a set of reference standards. Some of the most common standards used to assess water quality relate to health of ecosystems, safety of human contact and drinking 
water. Water quality index (WQI) is one of the most effective tools to communicate information on the quality of water to the concerned citizens and policy makers [9]. It is an important parameter for the assessment and management of water. It is calculated based on the suitability of water for human consumption [10].

The deterioration of water quality in the coastal areas due to saltwater intrusion into the freshwater aquifer has become a major concern in recent times. Due to the intrusion of seawater from tidal creeks, many communities in Delta State, Nigeria are facing an acute shortage of portable water. This compounded by increase in population, lack of pipe-borne water, industrial activities and crude oil exploration and exploitation. This has resulted to increase in groundwater consumption by the populace.

Freshwater is a limiting resource in many parts of the world, Nigeria inclusive. This problem will be compounded in the next century due to increased population, urbanization, pollution and climate change. Unfortunately, developing countries like Nigeria, the quality of drinking water is continuously being contaminated and posing hazardous for its population. Clean water is a priceless and limited resource that man has begun to treasure only recently after decades of pollution and waste [11]. The aim of this study is to assess the water quality of rivers around Warri metropolis in Delta state of Nigeria using water quality index (WQI).

\section{Materials and Methods}

\section{Area of study}

Warri is located between latitudes $5030^{\prime}$ and $5035^{\prime} \mathrm{N}$ 'and longitudes $5029^{\prime}$ and $5048^{\prime} \mathrm{E}$ (Fig. 1). It is within the oil rich province of Nigeria, some $50 \mathrm{~km}$ away from the shores of the Atlantic Ocean. It has a mean height of $6 \mathrm{~m}$ above sea level. The study area is traversed by an array and networks of creeks, rivers and streams all draining water into the Atlantic Ocean, with Warri River being the major river draining into the ocean. It is a flat land with very gentle slope towards River Warri. The study area enjoys a tropical climate with distinct rainy and dry seasons. The metropolis has an annual total rainfall of about $300 \mathrm{~cm}$ and a mean monthly temperature of $28^{\circ} \mathrm{C}$. Rainfall values range from as low as $2.4 \mathrm{~cm}$ (January) to as high as over $49.9 \mathrm{~cm}$ (September). The metropolis mostly experiences the convectional type of rainfall, with a relative humidity that fluctuates between $80 \%$ $90 \%$ [24]). The dry season commences from November and ends in the month of April while the rainy season commonly referred to as wet period starts from the month of May and ends in October of every year.

\section{Sample Collection and Data Analysis}

The river water samples were collected at an interval of 30 days for three months (October 2017 to January 2018) from fifteen (15) different sampling points at Ogunu, Airport Road, Ovwian, Otokutu, Opete, Ugbomoro, Jeddo, Ubeji, Effurun, Aladja, Eboh, Okuvo, Ekpan, NPA and Agbarho, Warri and analysed for thirteen (13) physio-chemicals parameters by following established procedures. The positions of the different water sources were determined using GPS (Table 1). 


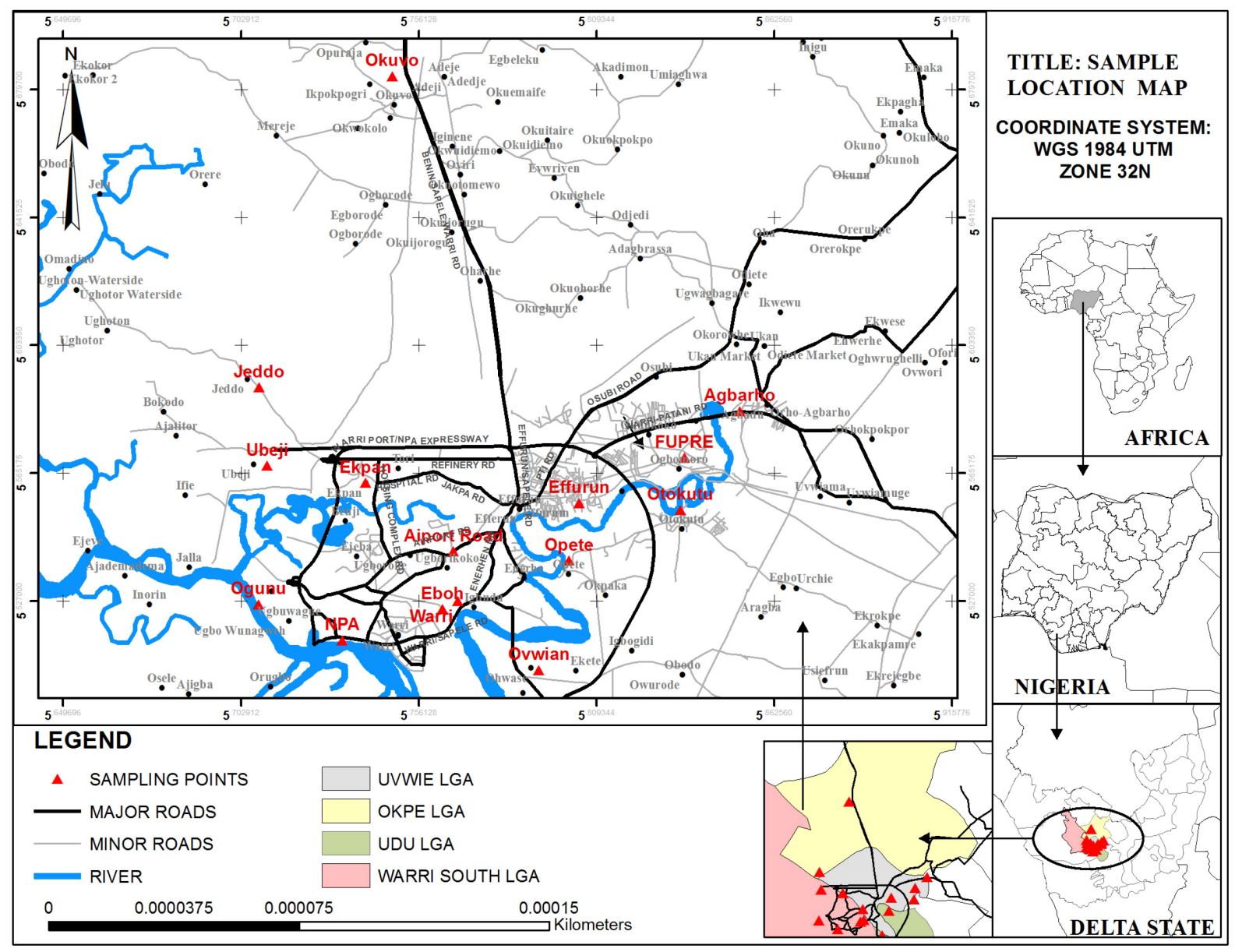

Figure 1. Map showing Warri metropolis and sampling locations

Table 1. Details of the Investigated Groundwater Sampling Locations

\begin{tabular}{|c|c|c|c|c|}
\hline \multirow[t]{2}{*}{$\mathbf{S} / \mathbf{N}$} & \multirow[t]{2}{*}{ Location } & \multirow[t]{2}{*}{ LGA } & \multicolumn{2}{|c|}{ Coordinates } \\
\hline & & & Northings & Eastings \\
\hline 1 & Ogunu & Warri South & $05^{\circ} 53^{\prime} 66^{\prime \prime}$ & $005^{\circ} 71^{\prime} 79^{\prime \prime}$ \\
\hline 2 & Airport Rd & Uvwie & $05^{\circ} 54^{\prime} 69^{\prime \prime}$ & $005^{\circ} 77^{\prime} 14^{\prime \prime}$ \\
\hline 3 & Ovwian & Udu & $05^{\circ} 29^{\prime} 84^{\prime \prime}$ & $005^{\circ} 46^{\prime} 92^{\prime \prime}$ \\
\hline 4 & Otokutu & Ughelli South & 05'33'01'” & 005'49'90', \\
\hline 5 & Opete & Udu & $05^{\circ} 32^{\prime} 50^{\prime \prime}$ & $005^{\circ} 48^{\prime} 33^{\prime \prime}$ \\
\hline 6 & Ugbomoro & Uvwie & 05'34'12'" & $005^{\circ} 50^{\prime} 08^{\prime \prime}$ \\
\hline 7 & Jeddo & Okpe & $05^{\circ} 60^{\prime} 40^{\prime \prime}$ & $005^{\circ} 70^{\prime} 13^{\prime \prime}$ \\
\hline 8 & Ubeji & Warri South & $05^{\circ} 57^{\prime} 44^{\prime \prime}$ & $005^{\circ} 70^{\prime} 12^{\prime \prime}$ \\
\hline 9 & Effurn & Uvwie & 05'33'18' & $005^{\circ} 48^{\prime} 36^{\prime \prime}$ \\
\hline 10 & Aladja & Udu & $05^{\circ} 48^{\prime} 97^{\prime \prime}$ & $005^{\circ} 75^{\prime} 77^{\prime \prime}$ \\
\hline 11 & Eboh & Warri South & $05^{\circ} 52^{\prime} 34^{\prime \prime}$ & $005^{\circ} 75^{\prime} 44^{\prime \prime}$ \\
\hline 12 & Okuvo & Okpe & $05^{\circ} 53^{\prime} 22^{\prime \prime}$ & $005^{\circ} 76^{\prime} 34^{\prime \prime}$ \\
\hline 13 & Ekpan & Uvwie & $05^{\circ} 55^{\prime} 59^{\prime \prime}$ & $005^{\circ} 74^{\prime} 40^{\prime \prime}$ \\
\hline 14 & NPA & Warri South & $05^{\circ} 30^{\prime} 56^{\prime \prime}$ & $005^{\circ} 43^{\prime} 58^{\prime \prime}$ \\
\hline 15 & Agbarho & Ughelli North & $05^{\circ} 34^{\prime} 60^{\prime \prime}$ & $005^{\circ} 51^{\prime} 05^{\prime \prime}$ \\
\hline
\end{tabular}

At each sampling location, water samples were collected in duplicate using clean water cans that has been washed and rinsed with distilled water. Before taking water samples, the bottles were rinsed three times with the water to be collected. Water samples for dissolved oxygen (DO) and biological oxygen demand (BOD) determination were collected in BOD bottles. In-situ analysis of water samples for parameters like $\mathrm{pH}$, electrical conductivity, dissolved oxygen, temperature, 
turbidity and total dissolved solids were measured at the sampling site, avoid unpredictable changes in water sample, while other parameter such as, total suspended solids, faecal coli form, sulphate, chlorides, nitrates, and biochemical oxygen demand were analysed in the laboratory (ex-situ) as per the standard procedures of [12]. After collection the samples were placed inside ice coolers for transportation to the laboratory where they were stored in the refrigerator at $4^{\circ} \mathrm{C}$ pending analysis. The samples for chemical analysis were carried out within 48 hours of collection.

The calculations of water quality index were based on thirteen (13) important parameters. The WQI was calculated using the standards of drinking water quality recommended by World Health Organisation [13] threshold for drinking water quality. The WQI of each community studied was determined to ascertain the suitability of the water for domestic purposes. This index was adopted because it has enjoyed wide usage amongst researchers and allows for the comparison of the water quality in different areas [14]. formula:

Mathematically, the quality rating or sub-index (qn) was calculated using the following

$$
\mathrm{Qn}=100(\mathrm{Vn}-\mathrm{Vio}) /(\mathrm{Sn}-\mathrm{Vn})
$$

where Qn - quality rating for the nth water quality parameter; Vn - estimated value of the nth parameter at a given sampling point; $\mathrm{Sn}$ - standard permissible value of the nth parameter; Vio - ideal value of nth parameter in pure water.

The unit weight was calculated by a value inversely proportional to the recommended standard value $\mathrm{Sn}$ of the corresponding parameter.

$$
\mathrm{Wn}=\mathrm{K} / \mathrm{Sn}
$$

where Wn - unit weight for the nth parameter; $\mathrm{Sn}$ - standard value for the nth parameter; $\mathrm{K}$ - constant for proportionality.

The overall WQI was calculated by aggregating the quality rating with the unit weight linearly

$$
\mathrm{WQI}=\Sigma \mathrm{qnWn} / \Sigma \mathrm{Wn}
$$

where WQI - water quality index; $\Sigma$ - summation; qn - quality rating for the nth water quality parameter; Wn - unit weight for the nth parameter.

\section{Water Quality Rating}

Table 2 shows the water quality index rating [15] and describes the range which each of the calculated water quality index falls into. The water quality is rated as Excellent, Good, Poor, Very poor and unsuitable/ unfit for drinking. Calculated WQI of 100 and above indicates that the water is unfit for drinking while low calculated index indicates excellent water fit for drinking.

Table 2. Water quality index rating table

\begin{tabular}{|c|l|l|}
\hline S/N & Water Quality Index (WQI) & Description \\
\hline 1 & $0-25$ & Excellent \\
\hline 2 & $26-50$ & Good \\
\hline 3 & $51-75$ & Poor \\
\hline 4 & $76-100$ & Very Poor \\
\hline 5 & $>100$ & Unfit for drinking \\
\hline
\end{tabular}

\section{Results and Discussion}

The results of the physio-chemical analysis of the water samples collected and analysed for fifteen locations are summarised in Table 3. The water quality for various sampling point varied greatly with temperature ranging between $26.0^{\circ} \mathrm{C}-29.9^{\circ} \mathrm{C}$, with the maximum temperature observed at NPA and minimum temperature at Opete sampling points. The $\mathrm{pH}$ values range from 5.4 to 6.7. All the $\mathrm{pH}$ values for the various locations were outside the regulatory standard $[16,17]$ except values recorded at Okuvo Station. Most water from this area has been observed to be acidic [18, 19]. While 
this may not constitute a serious health problem since the contents of the stomach are naturally acidic medium, it may pose significant problems in industries where it may aid corrosion. The $\mathrm{pH}$ mean values for the water were lower than the regulatory standards (Table 4).

The turbidity of the water ranged from 8.5NTU (Station 14) to 132NTU (Station 9) indicating a turbid water system for the metropolis. The high turbidity of the waterbody may be due to the various uses to which the rivers and stream are subject to including dumping of both wastewater and solids wastes as rivers moves around the metropolis. Various abattoirs are also located at the bank of some of these rivers [20]. The high turbidity of the waterbodies is also reflected in the total suspended solids and faecal coliforms.

Table 3. Recorded mean values of water physico-chemical parameters in the sampling sites

\begin{tabular}{|l|c|c|c|c|c|c|c|c|c|c|c|c|c|c|c|}
\hline Parameter & 1 & 2 & 3 & 4 & 5 & 6 & 7 & 8 & 9 & 10 & 11 & 12 & 13 & 14 & 15 \\
\hline $\mathrm{pH}$ & 5.55 & 6.26 & 5.56 & 5.55 & 5.40 & 6.33 & 5.39 & 6.70 & 5.98 & 6.27 & 6.08 & 6.08 & 6.43 & 5.55 & 5.92 \\
\hline Temp. & 26.1 & 27 & 26 & 26.1 & 28.7 & 29.3 & 28.5 & 27.3 & 28.2 & 27.4 & 26.4 & 27.4 & 29.9 & 26.6 & 26.5 \\
\hline Turb. & 13 & 38 & 17 & 25 & 102 & 35 & 102 & 55 & 118 & 119 & 82 & 97 & 114 & 9 & 18.5 \\
\hline Cond. & 33 & 55 & 33 & 33 & 50 & 48 & 50 & 50 & 51 & 39 & 42 & 53 & 51 & 24 & 39 \\
\hline D.O & 4.4 & 2.1 & 4.9 & 4.4 & 3.6 & 2.0 & 3.6 & 5.2 & 4.1 & 4.2 & 3.7 & 4.3 & 3.4 & 5.9 & 4.6 \\
\hline TDS & 17 & 27 & 17 & 17 & 25 & 24 & 25 & 25 & 26 & 19 & 21 & 26 & 25 & 12 & 19 \\
\hline Nitrate & 4.9 & 3.6 & 2.4 & 4.9 & 4.3 & 3.5 & 4.3 & 4.0 & 4.2 & 3.8 & 4.1 & 4.2 & 4.3 & 3.9 & 4.0 \\
\hline Chloride & 9.5 & 9.5 & 7.1 & 9.5 & 7.3 & 7.1 & 9.4 & 8.1 & 9.4 & 9.1 & 9.3 & 7.2 & 7.1 & 11.9 & 9.5 \\
\hline TSS & 20 & 40 & 20 & 28 & 115 & 24 & 113 & 65 & 122 & 124 & 86 & 91 & 120 & 10 & 32 \\
\hline Sulphate & 34.0 & 24.5 & 24.0 & 28.0 & 15.0 & 14.0 & 1.4 & 1.4 & 25.2 & 24.9 & 36.2 & 27.1 & 16.7 & 7.2 & 7.3 \\
\hline BOD & 2.0 & 1.3 & 2.1 & 2.2 & 1.7 & 1.5 & 1.4 & 2.1 & 2.1 & 2.1 & 1.9 & 2.2 & 1.6 & 2.1 & 2.1 \\
\hline Phosphates & 0.18 & 0.18 & 0.17 & 0.18 & 0.32 & 0.18 & 0.3 & 0.42 & 0.64 & 3.25 & 0.33 & 0.42 & 0.34 & 0.33 & 3.25 \\
\hline $\begin{array}{l}\text { Faecal } \\
\text { coliform }\end{array}$ & 14 & 12 & 2 & 14 & 14 & 12 & 14 & 14 & 16 & 14 & 10 & 11 & 14 & 4 & 12 \\
\hline
\end{tabular}

The microbiological analyses of the water indicate that faecal colifom microbial loads were observed in all the fifteen location. This indicates a high level of microbial load in all the surface waterbodies which makes the water unsuitable for drinking purposes except further treatment is carried out.

The TDS value is an index that represents the concentration of soluble salts in water $[12,21$, 22]. A high concentration of dissolved solids affects the taste of the drinking water [23]. The total dissolved solids and biological oxygen demand were generally low compared to national standards indicating fit-for-purpose potable water.

There was appreciable amount of chlorides in the water but when compared to the national and international standards, this value was within the limits of the set standards. The low chloride levels may indicate a low level of pollution from sewage. Other chemical constituents analysed like sulphates, nitrates and phosphates were all within the limits of regulatory standards.

Table 4. Calculated value of WQI from the various sampling sites

\begin{tabular}{|c|c|c|c|c|c|c|c|c|c|c|c|c|c|c|c|}
\hline Parameter & 1 & 2 & 3 & 4 & 5 & 6 & 7 & 8 & 9 & 10 & 11 & 12 & 13 & 14 & 15 \\
\hline $\mathrm{pH}$ & 7.73 & 8.72 & 7.74 & 7.73 & 7.52 & 8.81 & 7.51 & 9.33 & 8.33 & 8.73 & 8.47 & 8.47 & 8.95 & 7.72 & 8.24 \\
\hline Temp. & 2.89 & 2.94 & 2.83 & 2.84 & 3.13 & 3.19 & 3.1 & 2.97 & 3.07 & 2.98 & 2.87 & 2.98 & 3.26 & 2.9 & 2.89 \\
\hline Turb. & 52 & 152 & 68 & 100 & 312 & 140 & 288 & 220 & 328 & 288 & 328 & 388 & 376 & 36 & 74 \\
\hline Cond. & 0.005 & 0.01 & 0.008 & 0.05 & 0.005 & 0.015 & 0.005 & 0.005 & 0.005 & 0.008 & 0.009 & 0.01 & 0.025 & 0.002 & 0.005 \\
\hline D.O & 18.4 & 8.36 & 18.4 & 17.64 & 14.4 & 7.88 & 14.4 & 20.8 & 16.4 & 16.8 & 14.8 & 17.2 & 13.6 & 23.6 & 18.4 \\
\hline TDS & 0.01 & 0.02 & 0.019 & 0.011 & 0.011 & 0.031 & 0.011 & 0.01 & 0.009 & 0.015 & 0.184 & 0.24 & 0.06 & 0.006 & 0.01 \\
\hline Nitrate & 0.16 & 0.144 & 0.096 & 0.196 & 0.172 & 0.14 & 0.172 & 0.16 & 0.168 & 0.153 & 0.164 & 0.168 & 0.172 & 0.157 & 0.158 \\
\hline Chloride & 0.015 & 0.015 & 0.011 & 0.015 & 0.012 & 0.011 & 0.015 & 0.013 & 0.015 & 0.015 & 0.015 & 0.011 & 0.011 & 0.019 & 0.015 \\
\hline TSS & 80 & 160 & 112 & 80 & 180 & 176 & 180 & 260 & 168 & 248 & 304 & 328 & 480 & 40 & 112 \\
\hline Sulphate & 0.012 & 0.039 & 0.038 & 0.045 & 0.024 & 0.055 & 0.002 & 0.002 & 0.04 & 0.04 & 0.058 & 0.043 & 0.075 & 0.012 & 0.012 \\
\hline BOD & 8.4 & 5.2 & 8.4 & 8.8 & 6.8 & 6.2 & 5.6 & 8.4 & 8.4 & 8.4 & 7.6 & 8.8 & 6.4 & 8.4 & 8.4 \\
\hline Phosphates & 0.28 & 1.68 & 0.47 & 0.48 & 0.32 & 1.88 & 0.32 & 0.42 & 0.64 & 3.25 & 0.33 & 0.42 & 0.33 & 0.33 & 3.25 \\
\hline$\Sigma$ Wnqn & 169.9 & 339.13 & 218 & 217.8 & 524.4 & 344.2 & 499.1 & 522.11 & 533.1 & 576.4 & 666.5 & 754.3 & 888.9 & 119.2 & 227.4 \\
\hline$\Sigma \mathrm{Wn}$ & 1.082 & 1.082 & 1.082 & 1.082 & 1.082 & 1.082 & 1.082 & 1.082 & 1.082 & 1.082 & 1.082 & 1.082 & 1.082 & 1.082 & 1.082 \\
\hline$\Sigma W n q n / \Sigma W n$ & 157 & 313.43 & 201.5 & 201.3 & 484.7 & 318.1 & 461.3 & 482.54 & 492.7 & 532.7 & 616 & 697.2 & 821.5 & 110.12 & 210.15 \\
\hline
\end{tabular}


The calculated water quality index (WQI) in Table 4 showed that the index for the locations range from 110.1 (Station 14) to 821.5 (Station 13) indicating the water quality to be unfit for drinking purpose. This observation may be not be surprising as most of the Metropolis are noted for not practising good waste management both for solid and wastewater disposal. It should be noted that during the sampling exercise heaps of solid wastes were observed stacked by the banks of river, while most household were observed to channel their wastewater direct into the rivers and streams behind their houses. Solid wastes were also observed floating on the rivers. Some of the urban areas with industries and factories located within their locations were also observed not practising good waste disposal. Overall the results indicate that the different surface water samples analysed from Warri Metropolis are not safe for human consumptions but need further treatment.

In the study, the WQI is established from important physio-chemical parameter such as $\mathrm{pH}$, temperature, dissolved oxygen, electrical conductivity, total dissolved solids, total suspended solids, sulphates, chlorides, nitrates, turbidity, phosphates, biochemical oxygen demanded and faecal coliform.

The WQI result obtained from the different sampling stations were founded to vary from 236.9 to 924.5 for river water. The results which is very high, indicates that the different water samples analysed from river are not safe for human consumptions but can be used for some domestics' purposes such as irrigation, transportation etc.

Table 4. Summary of calculated WQI of the various surface water sources

\begin{tabular}{|c|l|c|l|}
\hline S/N & Sample Source & $\begin{array}{c}\text { Water Quality Index } \\
\text { (WQI) }\end{array}$ & Quality \\
\hline 1 & Ubeji & 532.7 & Unfit for drinking \\
\hline 2 & Aladja & 318.1 & Unfit for drinking \\
\hline 3 & NPA & 821.5 & Unfit for drinking \\
\hline 4 & Okuvo & 482.5 & Unfit for drinking \\
\hline 5 & Airport Road & 484.7 & Unfit for drinking \\
\hline 6 & Eboh & 461.3 & Unfit for drinking \\
\hline 7 & Ekpan & 492.7 & Unfit for drinking \\
\hline 8 & Jeddo & 616.0 & Unfit for drinking \\
\hline 9 & Otokutu & 157.0 & Unfit for drinking \\
\hline 10 & Ovwian & 313.4 & Unfit for drinking \\
\hline 11 & Opete & 201.2 & Unfit for drinking \\
\hline 12 & Ugbomro & 201.3 & Unfit for drinking \\
\hline 13 & Ogunu & 697.2 & Unfit for drinking \\
\hline 14 & Effurun & 110.1 & Unfit for drinking \\
\hline 15 & Agbarho & 224.9 & Unfit for drinking \\
\hline
\end{tabular}

\section{Conclusions}

From the information deduced from this study using water quality index, all the surface samples were found to be unfit for human consumption. This may be due primarily to the human activities that are carried out along the river basin catchment areas; such as dumping of solid waste, disposal of untreated wastewater and location of abattoirs along the water course. Most residents along the river course make use of the water without for drinking, food preparation and other domestic activities without further treatment. This water when consumed without treatment may have detrimental effect on consumers especially with the presence of faecal coliform. In the short term, surface water from the noted areas should be subjected to treatment before consumption, while in the long term, an effective monitoring plan should be put in place by both local and state government to help safeguard discharge of untreated wastes into the waterbodies, while at the same time appropriate regulations enacted and defaulters sanctioned appropriately. 


\section{References}

[1] UNESCO Water Ethics and Water Resource Management. Ethics and Climate Change in Asia and the Pacific (ECCAP) Project Working Group 14 Reports. Published by UNESCO 2011 Bangkok.

[2] P.K. Panda, R.B. Panda, P.K. Dash, Assessment of water quality index of River Salandi at Hadagada Dam and its down stream up to Akhandalmani, Bhadrak, Odisha, India, American Journal of Water Resources. 4(2) (2016) 44-53.

[3] S.A. Salami, E.M. Babafemi, Geophysical survey for groundwater investigation in Ogbe, Akoko-Edo Local Government Area, South-western Nigeria, Nigerian Journal of Applied Science. 35 (2017) 31-42.

[4] G.T. Miller, Environmental Science: Working with the Earth. (6 $6^{\text {th }}$ Ed), California: Wadsworth Publishing Company, 1997

[5] F.O. Okeola, O.D. Kolawole, O.M. Ameen, Comparative study of physic-chemical parameters of water from a River and its surrounding wells for possible interactive effect, Advances in Environmental Biology. 4(3) (2010) 336-344.

[6] V.E. Agbazue, The chemist and self-employment, in: Book of Proceeding of the International Conference of the Chemical Society of Nigeria, Effurun, Delta State, 2008.

[7] UNEP/WHO, Water Quality Monitoring - A Practical Guide to the Design and Implementation of Freshwater Quality Studies and Monitoring Programmes. Edited by Jamie Bartram and Richard Ballance. Published on behalf of United Nations Environment Programme and the World Health Organization, 1996.

[8] D.L Johnson et al., Meanings of environmental terms, Journal of Environmental Quality. 26 (1997) 58-89.

[9] J. Yisa, T. Jimoh, Analytical studies on water quality index of river Land zu, American Journal of Applied Sciences. 7(4) (2017) 453-458.

[10] P.U. Atulegwu, J. D. Njoku, The impact of biocides on the water quality, Int. Res. J. Eng. Sci. Technol. 1 (2004) 47-52.

[11] M.S. Silderberg, Higher Education Chemistry. The Molecular Nature of Matter and Change, McGraw Hill, 2003.

[12] APHA, AWWA, WEF Standard Method for the examination of Water and Wastewater 18th edition, American Public Health Association, Washington, DC, 1999, pp.45-60.

[13] WHO, Guidelines for Drinking water Quality. International Standard for Drinking Water Guidelines for Water Quality, $4^{\text {th }}$ ed, Geneva, Switzerland, 2011.

[14] A. B. M. Egborge, Water Pollution in Nigeria: Biodiversity and Chemistry of Warri River, Benin City, Ben Miller Books Nigeria Limited, 1994.

[15] C. Chatterrji, M. Raziuddin, Determination of water quality index (WQI) of a degraded river in Asanol Industrial are, Raniganj, Burdwan West Bengal, Nature, Environment and Pollution Technology. 1(2) (2002) 181-189.

[16] NIS, Nigerian Standard for Drinking Water Quality. Nigerian Industrial Standard 554, 13-14. Plot 1687, Lome Street, Wuse Zone 7, Abuja, Nigeria, 2007.

[17] WHO, International Standard for Drinking Water Guidelines for Water Quality, Geneva. 2017.

[18] O.T. Isichei, D.F. Ogeleka, F.E. Okieimen, Consideration of the groundwater quality in Effurun Metropolis, Bulletin of GeoEnvironmental and Climate Change Adaptation Research. 4 (2015)1-40. 
[19] I.E. Uwidia, Comparative analysis of borehole water and some selected bottled water sold in Benin-City, Nigerian Journal of Applied Science. 35 (2017) 172-180.

[20] G. Asibor, O. Edjere, P. Ofejiro, Physico-chemical and bacteriological assessment of abattoir effluents and its effects on Agbarho River, Delta State Nigeria, Journal of Applied Science. 35 (2017) 265-276.

[21] P. Gupta, M. Vishwakarma, P. M. Rawtani, Assessment of water quality parameters of Kerwa Dam for drinking suitability, International Journal of Theoretical \& Applied Sciences. 1(2) (2009) 53-61.

[22] B.L. Kumari et al., Analysis of physico-chemical parameters of water quality in and around Saltpans of Prakasam, Journal of Ecobiotechnology. 3(10) (2011)1-12.

[23] A. Aydin, The microbiological and physico-chemical quality of groundwater in West Thrace, Turkey, Pol. J. Environ. Stud. 16(3) (2007) 377-386.

[24] R. Olanrewaju, B. Ekiotuasinghan, G. Akpan, Analysis of rainfall pattern and flood incidences in Warri Metropolis, Nigeria, Geography, Environment, Sustainability. 10(4) (2017) 83-97. 